\title{
The Impact of Growing Legume Plants under Conditions of Biologization and Soil Cultivation on Chernozem Fertility and Productivity of Rotation Crops
}

\author{
Almas Mukhametov¹, Nana Bekhorashvili², Aleksei Avdeenko³, Alexey Mikhaylov ${ }^{4}$
}

10.18805/LR-573

\begin{abstract}
Background: The combined use of green manure and legumes in binary legume-crop mixtures allows farmers to efficiently produce a sufficient amount of human food and animal feed. The purpose of this study is examine how biologization and the use of different soil cultivation techniques in legume cropping affects chernozem soil fertility and productivity of rotation crops.

Methods: The studies were conducted between 2017 and 2019 in 3 crop rotations. The first (control) crop rotation comprised of a clean fallow phase, winter wheat, barley and sunflower. The second crop rotation was that of green-manure fallow (clover), winter wheat, barley, sunflower and clover with oilseed radish as green manure. The third crop rotation included alfalfa, winter wheat combined with alfalfa, followed by barley, followed by sunflower and alfalfa with oilseed radish as green manure.

Result: The three-year data indicated that there was an improvement in the physical properties of soil. The water resistance of soil aggregates increased by 9.7 per cent. There was a steady tendency towards an increase in detritus content (1.5 times), the amount of soil aggregates (one-third) and water resistance of the soil aggregates (9 per cent).
\end{abstract}

Key words: Agroecosystems, Alfalfa, Binary crops, Legumes, Organic farming, Permaculture.

\section{INTRODUCTION}

The long-term use of land in monoculture farming typically has negative consequences. Even so, the practice of growing monocultures is conducive to high harvest efficiency and productivity, especially when mineral and organic fertilizers are applied (Semedo 2017). The result of monoculture farming is agrocenosis formation. Agrocenosis is an unstable ecosystem that comes under attack from pests that can partially or completely destroy crops in one or two seasons. The ease with which pests spread across the agrocenosis results from its monocultural composition where conditions are favorable to pest development (Ponisio et al. 2014). Fertilizers fail to create a long-term positive effect, since at least 50 per cent of nutrients applied to the soil is leached out and the amount that does reach the plant may be harmful. At the same time, the intensive land use can lead to the exhaustion and degradation of land, cause the loss of organisms on different trophic levels and facilitate the depletion of soil microflora (Akhtar et al. 2016). Considering that soil is a basic medium for plant growth, soil degradation can entail disturbances within phytocenosis and zoocenosis.

Farmers across the world are seeking to avoid the above problems. For this, they decided to abandon the traditional ways of treating the land that involve mechanized tillage and the use of chemicals. The alternative is organic farming, which advocates for the mechanical treatment of soil without using pesticides and other toxic substances (Salleh et al. 2018). This practice is conducive to agriculture biologization. Organic farming is widely practiced in many developed and developing countries such as the USA, Canada, Australia, Kenya, Malaysia, etc. Thus, transitioning
1Department of Technology and Safety of Food Products, Kazakh National Agrarian Research University, Almaty, Kazakhstan.

${ }^{2}$ Department of Regulatory Relations on the Circulation of Parmateuticals and Medical Products, Sechenov First Moscow State Medical University, Moscow, Russian Federation.

${ }^{3}$ Department of Agriculture and Storage Technologies for Crop Products, Don State Agrarian University, Persianovsky, Russian Federation.

${ }^{4}$ Financial Research Institute of Ministry of Finance of the Russian Federation, Moscow 127006, Russian Federation.

Corresponding Author: Aleksei Avdeenko, Department of Agriculture and Storage Technologies for Crop Products, Don State Agrarian University, Persianovsky, Russian Federation.

Email: avdeenkoal@rambler.ru

How to cite this article: Mukhametov, A., Bekhorashvili, N., Avdeenko, A. and Mikhaylov, A. (2021). The Impact of Growing Legume Plants under Conditions of Biologization and Soil Cultivation on Chernozem Fertility and Productivity of Rotation Crops. Legume Research. 44(10): 1219-1225. DOI: 10.18805/LR-573.

Submitted: 01-07-2020 Accepted: 23-07-2021 Online: 17-09-2021

from conventional to organic production takes place on a global scale (Symanczik et al. 2017).

The main idea of organic farming is to improve soil fertility without causing harm to the environment. In organic production, the anthropogenic influence on ecosystems is minimal. One of the advantages of organic agriculture is the production of safe products. Thus, organic farming has multifaceted positive effects on human health and ecosystem (de Tombeur et al. 2018a). Organic practices include, but 
The Impact of Growing Legume Plants under Conditions of Biologization and Soil Cultivation on Chernozem Fertility...

are not limited to: using compost and organic manure; encouraging beneficial insects to control pests; using natural soil amendments; and reducing tillage (Hirschfeld and Van Acker 2019). On average, organic products are 20 to 30 percent more expensive, but sticking to organic practices will allow keeping the soil fertile (Vitari and David 2017).

Biologization of agricultural systems involves grass cultivation, polyculture adoption and the use of break crops. It is expected that at least one-quarter of arable land will be covered with grasses. At the same time, crop residues are not removed from the field. Deep cultivation is prohibited in order to keep the soil microstructure intact (de Tombeur et al. 2018b). Sometimes, organic farming avoids or minimizes soil disturbance. Even the native plants may be kept. This enables the creation of a stable agroecosystem that is neither a natural phytocenosis, nor a typical monoculture system, but something in the between. Normally, an agroecosystem contains both a crop and a native weed species (Udomkun et al. 2019). A sustainable agroecosystem design depends upon several important factors such as soil microrelief, soil microclimate and more. Crop species are incorporated into a natural setting that is stable and where trophic relationships are strong. The enrichment of soil is carried out without application of fertilizers. The disadvantage of this approach is that it is not suitable for vast areas, at least for now (Sharma 2017). Furthermore, permaculture systems that receive nonchemical enrichments will not provide yields that are as high as those obtained through traditional methods. Nevertheless, permacultures have obvious advantages over traditional system designs. For instance, they provide a deeper assortment of products. Permaculture designs are complex. Although they allow a vast range of crops, the harvests are relatively small. This type of organic practice is ideal for small farms (Hathaway 2016) that seek to meet mass demand. The bottom line is that the quality of organic products will be higher than that of products obtained through conventional farming.

In the shortage of financial and material-technical resources and because of price imbalances and climate anomalies observed in recent years, expanding the cultivation of perennial legumes and cereals became one of the major directions taken in agriculture to improve land fertility (Didur et al. 2020; Patil et al. 2020). Growing more grain legumes to harvest more protein-rich seeds is among the crucial strategies used by farmers to enhance the production of vegetable protein (Wobeng et al. 2020). Cereals are not only an important source of vegetable protein, but also an essential component of alternative farming systems. Perennial grasses serve as the basis for forage production, while perennial legumes with a welldeveloped root system facilitate soil fertility by leaving behind a large amount of organic matter, which improves soil structure and enriches it with nitrogen (Yadav et al. 2019). The phytosanitary role of perennial grasses is also tremendous: they create unfavorable conditions for many types of weeds, enabling the control of weed seeds and cause many pests and pathogenic microflora to die. That aside, perennial grasses are an effective means of protecting soil from water and wind erosion (Xiong et al. 2012). When decomposing in the presence of oxygen, perennial grass residues form humus, the fraction of the soil medium that improves the solubility of soil minerals. The process of organic matter mineralization takes place. Plant residues provide beneficial soil microorganisms with energy necessary for vital activity (Wang et al. 2014).

Using a mixture of perennial legumes and cereals is better than planting them separately. The advantage lies in the fact that the root system of perennial cereals develops largely in the arable horizon and after decaying, facilitates the development of aerobic bacteria. Perennial legumes, on the other hand, root deeply into the soil and transfer nutrients (phosphorus and calcium) to the upper horizons (Verde et al. 2013). The value of the perennial layer is that their roots, which contain a substantial amount of proteins, carbohydrates and other organic substances, are plowed into the soil. Roots of some legumes, including, but not limited to, clover and alfalfa, contain a lot of nitrogen and calcium (Tuyen et al. 2016).

One of the organic farming practices is legume cultivation. Legumes are used as nitrogen suppliers because of their ability to fix atmospheric nitrogen in symbiotic associations with soil bacteria (Kaushik et al. 2018). They also can make up a substantial part of the human diet, yet they fail to fully replace meat. Moreover, legumes contain anti-nutritional compounds such as tannins and vicin that can degrade the taste of food. For this reason, legumes such as clovers and alfalfa are commonly used as fodder crops (Smith and Lampkin 2019).

Another promising method is the use of brake crops. This technique has long been known to farmers, yet it was not widely used until now. In modern agroecology, cereal and bean fodder mixtures are most often considered. The idea of brake crop cultivation is to enrich soil after it has been exhausted from growing soil-depleting crops. The literature provides evidence on the effectiveness of rotations such as winter wheat/winter vetch, buckwheat/millet, lupine/ spring wheat or barley and sunflower/winter wheat + legumes (de Tombeur et al. 2018a, 2018b; Roberts 2017).

This study examines the binary mixtures of legumes with cereals and sunflower crops. Our study is dedicated to the study of binary sunflower crops with legumes. The relevance of the study lies in the absence of similar studies that use biologization techniques (sideration and fertilization with straw of cereal crops) when growing sunflower. The purpose of this study is to investigate how biologization and the use of different soil cultivation techniques in legume cropping affects chernozem soil fertility and productivity of rotation crops.

The results may be used in farms with a similar soil and similar microclimatic conditions. The joint and simultaneous coexistence of several agricultural crops will 
significantly complicate the structure of the plant community, causing a shift to an equilibrium.

\section{MATERIALS AND METHODS Materials}

The studies were conducted in 2017-2019 in the Moscow region (Russian Federation). The experimental sites were located within the State Agrarian Administration. The soils in plots were loamy chernozemic ones containing 5.5 per cent of humus in the upper horizon (up to $0.3 \mathrm{~m}$ thick). The soil $\mathrm{pH}$ was 5.4. On average, the amount of mobile potassium and phosphorus in soil was 185 and $115 \mathrm{mg}$ per kilogram of soil. The hydrothermal coefficient (SCC) accounting for moisture availability was 1.6 in 2017 and 1.8 in 2018, indicating moderate humidity of soil. In 2019, it was 1.0 , indicating low humidity of soil (arid year).

The hydrothermal coefficient was calculated using the following formula:

\section{Where}

$$
K=R^{*} 10 / \Sigma t
$$

$\mathrm{R}$ represents total precipitation (in millimeters) for the period with average daily temperature above $+10^{\circ} \mathrm{C}$ and $\Sigma \mathrm{t}$ is the average temperature $\left({ }^{\circ} \mathrm{C}\right)$ over the same period.

Based on the value of the hydrothermal coefficient, the following zones can be distinguished: (1) zone of excessive moisture (SCC >1.3); (2) zone of suffiecient moisture $(\mathrm{SCC}=1.0-1.3)$; (3) arid zone (SCC=0.7-1.0); (4) dry zone $(\mathrm{SCC}=0.5-0.7)$ and $(5)$ zone of irrigation $(\mathrm{SCC}<0.5)$.

\section{Study design}

The experiments were planned and implemented according to the standard field experiment methodology. Crops were planted in triplicate plots in a systematic manner. The total area of trial field was 800 square meters, of which 690 square meters accounted for trial plots.

There were three crop rotations. The first (control) crop rotation includes the following phases: clean fallow, winter wheat, barley and sunflower. The second crop rotation includes a green-manure fallow covered with clover, winter wheat, barley and sunflower with clover + oilseed radish as green manure. The third crop rotation includes alfalfa, winter wheat with alfalfa, barley, followed by the double cropping of sunflower and alfalfa with oilseed radish as green manure.

\section{Methods}

Soil structure was evaluated via aggregate analysis. This method was to establish the relative quantity of aggregates of different size in the soil. The aggregates were separated using a standard set of sieves with a mesh diameter of 10 ; $7 ; 5 ; 3 ; 2 ; 1 ; 0.5$ and $0.25 \mathrm{~mm}$. To determine water resistance of soil aggregates, 10-20 aggregates of each fraction were placed in a crystallizer or a large-diameter porcelain dish. The aggregates were distributed over the bottom of the dish at equal distances from each other. Tap water was poured into a dish so that the aggregates were covered with about $2 \mathrm{~cm}$ of water. After $20 \mathrm{~min}$, each aggregate was carefully moved with a glass rod. We counted both the destroyed and the intact aggregates.

The content of active organic matter (detritus) was determined by the Tyurin's method. A 3 to $5 \mathrm{~g}$ sample of soil was taken for fine grinding. The visible, non-decomposed plant residues were removed manually with tweezers. The sample was then crushed and passed through a woven sieve with holes $0.25 \mathrm{~mm}$ in diameter. For fine grinding, mortars and grinding devices made of porcelain, steel and other hard materials were used. The mass of the organic matter in the sample was determined using a calibration graph. When building a calibration curve, the mass of the organic matter (in milligrams), which corresponds to the volume of a reducing agent in the reference solution, was plotted on the abscissa, whilst the device readings were plotted on the ordinate.

\section{Soil treatment}

Soil under sunflower crops was cultivated using different techniques: plowing to a depth of $20-24 \mathrm{~cm}$; tillage to a depth of 10-12 cm with disc harrows; and tillage to a depth of 20$24 \mathrm{~cm}$ with cultivators. Soil samples were taken at three different intervals: spring legume seedlings; crop flowering; and crop ripening. Soil samples from fallow plots were collected before planting winter wheat.

\section{Statistical analysis}

Data processing was carried out with Statistica 7.0 (StatSoft Inc). Tables present means and standard deviations. The Student's t-test was used to compare the two samples and trace changes in one parameter (e.g., yield). The results are given in percentages to make the dynamics more evident. The reliability of results was evaluated through independent t-test. Differences were considered significant at $\mathrm{p} \leq 0.05$.

\section{RESULTS AND DISCUSSION}

The experiments show that the use of legumes such as alfalfa and clover in crop rotation allows preserving and improving soil fertility, as evidenced by data from biological soil analysis and crop yield observations.

Data in Table 1 show a decrease in soil water content in the 1-meter soil layer during the growing season. The best moisture conditions were observed after winter wheat with alfalfa in the third year. During the experiment with wheat alone, the quantity of water contained in soil was lower $(p=0.05)$.

In the two-crop experiments with alfalfa, the structural change of soil was detected. Fig 1 shows an upward trend in the number of soil aggregates in the second year, with the annual growth ranging between 13 and 14 per cent. In the first year, the difference was not significant, but in the second year, the amount of soil aggregates doubled, reaching 28 per cent. The third year saw a 5 per cent increase after winter wheat with alfalfa. Over the three-year period, the overall degree of soil aggregation was improved by 8 per cent. In the control experiment, the soil aggregation parameter decreased by 47 per cent, by contract $(p=0.001)$. 
The Impact of Growing Legume Plants under Conditions of Biologization and Soil Cultivation on Chernozem Fertility...

In addition to the structural effect, the use of legumes had a significant impact on water resistance (Fig 2). In the experiment without legumes, the water resistance of soil aggregates dropped 3 per cent, whilst after the use of companion crop (alfalfa), this parameter demonstrated 2.4percent improvement $(p=0.05)$. This trend continued into the second year: in the two-crop experiment with alfalfa, the water resistance parameter increased by 5 per cent; in the one-crop experiment without legumes, it decreased by 4 per cent. In the third year, the water resistance parameter after winter wheat with alfalfa was found to increase by 4.3 per cent. Overall, the total increase of water resistance was 9.7 per cent.
The experiments revealed a change of detritus content (Fig 3). The amount of detritus in the control plot dropped by 40.2 per cent over the study period. The use of pioneer plants resulted in up to 71 per cent increase of detritus $(p=0.001)$. Depending on the crop mixture, the following results were obtained. The amount of detritus after sunflower with alfalfa was 1.6 times higher compared to control. Other crop mixes were less effective. Alfalfa alone provided 1.3 times more dead biomass than the control, whilst winter wheat with alfalfa was conducive to 1.2 times higher amount of detritus.

The best mineral content of soil was recorded after twocrop experiments with alfalfa. The change of phosphorus

Table 1: Changes over time in soil moisture at 0.01-1.0 m depth across crop rotations (2017-2019, in mm per $1 \mathrm{~m}$ of soil over the growing period).

\begin{tabular}{|c|c|c|c|c|c|c|}
\hline \multirow{2}{*}{ Sampling interval } & \multirow{2}{*}{ Clean fallow } & \multirow{2}{*}{ Winter wheat } & \multirow{2}{*}{ Barley } & \multicolumn{3}{|c|}{ Sunflower } \\
\hline & & & & Plowing & Disk harrows & Cultivator \\
\hline \multicolumn{7}{|l|}{ Crop rotation 1} \\
\hline Seedling & $151 \pm 3.3$ & $165 \pm 4.2$ & $154 \pm 5.7$ & $195 \pm 6.5$ & $189 \pm 6.3$ & $198 \pm 10.1$ \\
\hline Flowering & $199 \pm 3.2$ & $184 \pm 3.4$ & $127 \pm 5.6$ & $182 \pm 4.5$ & $185 \pm 5.4$ & $180 \pm 6.5$ \\
\hline Ripening & $161 \pm 2.1$ & $89 \pm 1.1$ & $87 \pm 2.7$ & $128 \pm 4.1$ & $131 \pm 2.9$ & $135 \pm 4.1$ \\
\hline \multicolumn{7}{|l|}{ Crop rotation 2} \\
\hline Seedling & $138 \pm 6.4$ & $151 \pm 7.1$ & $162 \pm 4.2$ & $187 \pm 12.1$ & $169 \pm 3.6$ & $210 \pm 10.2$ \\
\hline Flowering & $179 \pm 4.3$ & $168 \pm 5.5$ & $120 \pm 6.1$ & $150 \pm 9.4$ & $149 \pm 3.8$ & $163 \pm 12.1$ \\
\hline Ripening & $143 \pm 21$ & $80 \pm 6.5$ & $91 \pm 6.9$ & $125 \pm 3.1$ & $110 \pm 3.8$ & $152 \pm 8.5$ \\
\hline \multicolumn{7}{|l|}{ Crop rotation 3} \\
\hline Seedling & $145 \pm 12.1$ & $172 \pm 17.7$ & $199 \pm 23.4$ & $171 \pm 13.6$ & $183 \pm 3.2$ & $192 \pm 7.5$ \\
\hline Flowering & $172 \pm 8.8$ & $174 \pm 9.7$ & $200 \pm 21.1$ & $140 \pm 9.4$ & $180 \pm 14.1$ & $161 \pm 13.2$ \\
\hline Ripening & $175 \pm 7.5$ & $92 \pm 3.7$ & $107 \pm 9.9$ & $141 \pm 13.0$ & $159 \pm 11.4$ & $154 \pm 9.3$ \\
\hline
\end{tabular}

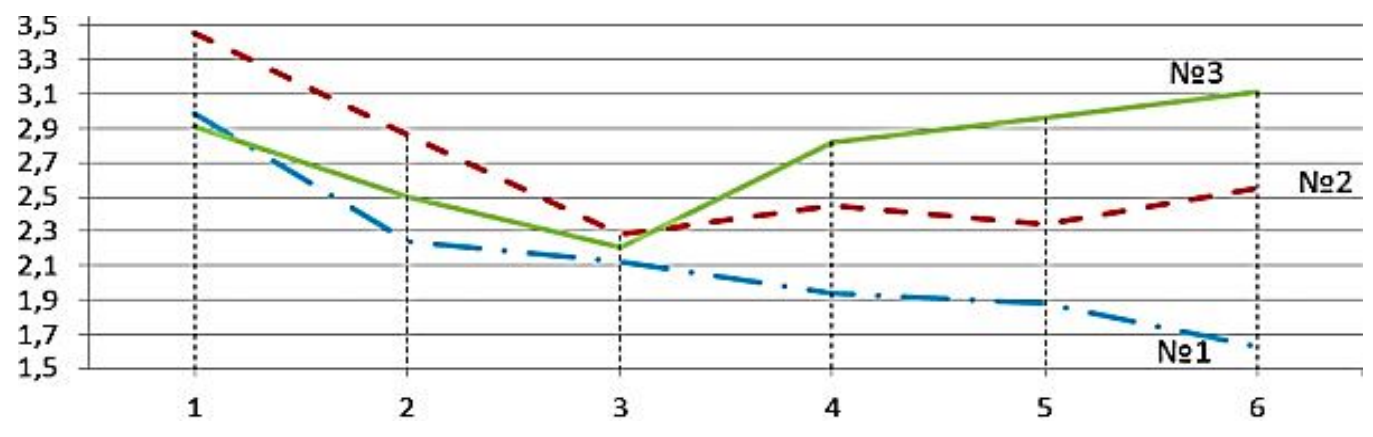

Fig 1: Changes in soil structure across crop rotations, $\mathrm{g} / \mathrm{cm}^{3}$ (2017-2019); all crop rotations are numbered.

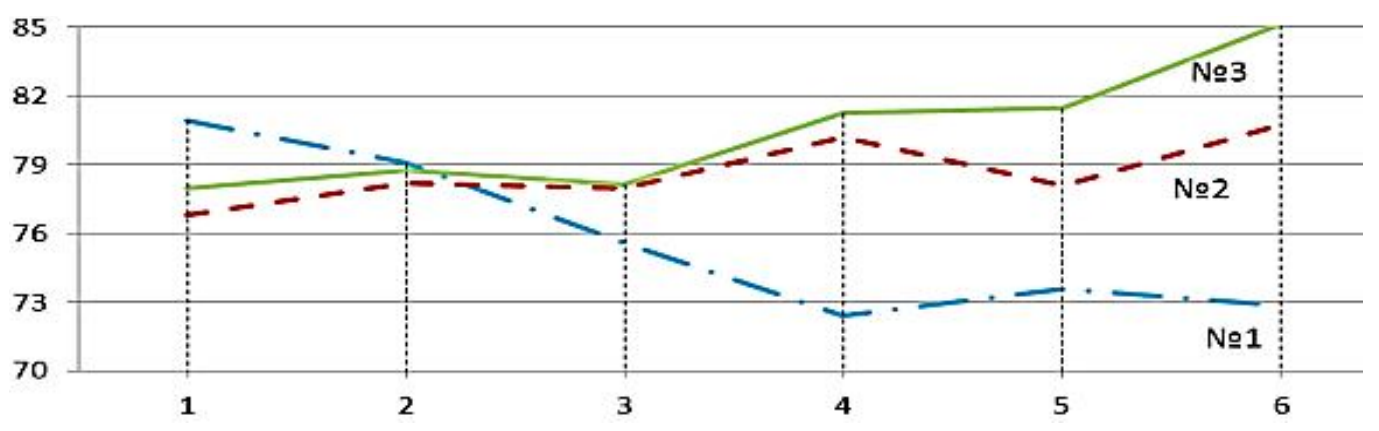

Fig 2: Changes over time in water resistance of soil aggregates across crop rotations, \%; all crop rotations are numbered. 
The Impact of Growing Legume Plants under Conditions of Biologization and Soil Cultivation on Chernozem Fertility...

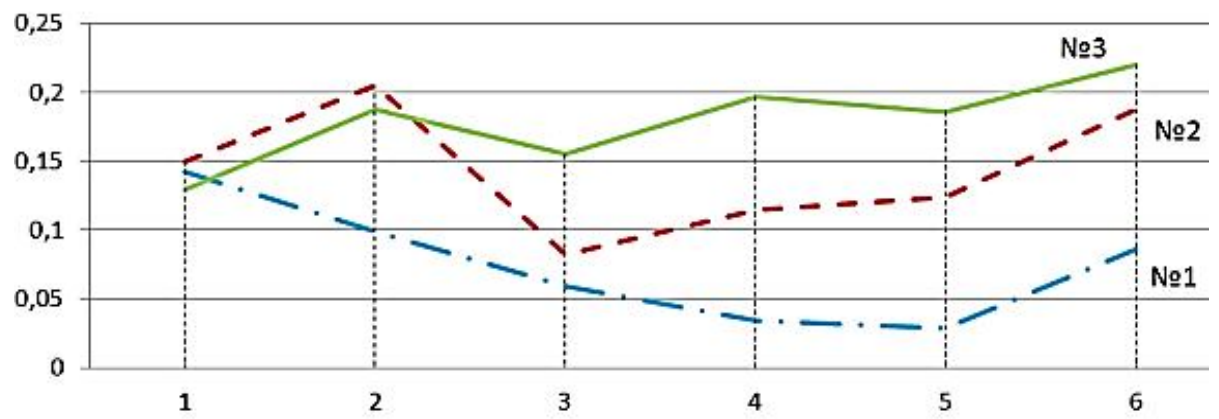

Fig 3: Changes over time in detritus content across crop rotations, \%; all crop rotations are numbered.

Table 2: Average crop yields across crop rotations (2017-2019).

\begin{tabular}{|c|c|c|c|c|c|c|}
\hline \multirow{2}{*}{ Yield } & \multirow{2}{*}{ Clean fallow } & \multirow{2}{*}{ Winter wheat } & \multirow{2}{*}{ Barley } & \multicolumn{3}{|c|}{ Sunflower } \\
\hline & & & & Plowing & Disk harrows & Cultivator \\
\hline \multicolumn{7}{|l|}{ Crop rotation 1} \\
\hline Centners per 1 ha & - & $45.7 \pm 1.4$ & $39.7 \pm 2.9$ & $29.5 \pm 1.7$ & $27.7 \pm 1.3$ & $27.0 \pm 1.1$ \\
\hline$\%$ with respect to control & - & 100 & 100 & 100 & 91.9 & 90.2 \\
\hline \multicolumn{7}{|l|}{ Crop rotation 2} \\
\hline Centners per 1 ha & - & $43.1 \pm 2.2$ & $39.8 \pm 1.7$ & $30.6 \pm 2.1$ & $29.7 \pm 1.9$ & $28.1 \pm 0.9$ \\
\hline Share in $\%$ in relation to control & - & 95.7 & 101.7 & 101.9 & 98.2 & 94.9 \\
\hline \multicolumn{7}{|l|}{ Crop rotation 3} \\
\hline Centners per 1 ha & - & $41.9 \pm 2.1$ & $40.9 \pm 1.7$ & $31.7 \pm 1.5$ & $30.2 \pm 1.1$ & $32.5 \pm 1.4$ \\
\hline$\%$ with respect to control & - & 94.2 & 104.2 & 108.6 & 104.1 & 105.6 \\
\hline
\end{tabular}

ranged between 6 and 8 per cent depending on the type of soil treatment. The change of mobile potassium varied between 6 and 19 per cent. In the control experiment, phosphorus and potassium content decreased by 10 and 5 percent, respectively. The difference between fallow and binary crop mixture is significant $(p=0.001)$.

The above factors had a very significant impact on crop yields (Table 2). Sunflower yields were found to be excessive in two-crop experiments with alfalfa regardless of the type of soil treatment. Yields were higher by 3 to 8 per cent than those from the control experiments $(p=0.05)$. The winter wheat yields in two-crop experiments, however, were lower compared to the control $(p=0.05)$. The barley yields were higher when planted after winter wheat with alfalfa.

At the present stage of agricultural development, chernozem soils experience degradation caused by the insufficient use of expensive mineral and organic fertilizers (Tadele 2020). Therefore, it is necessary improve the cropping systems to concentrate primarily at preserving and increasing soil fertility. In this light, there is an urgent need to develop recommendations for the use of biologization techniques in crop cultivation to increase the content of organic matter in the soil. The present work closes this gap. Binary sowings of crops with perennial legumes and the combined use of stubble crops and grain straw for fertilization can be effective when enhancing chernozem fertility (Sun et al. 2020). At the same time, the rate of residue decomposition is a crucial aspect of impact crop residues have on soil fertility (Verde et al. 2013).
The traditional farming practices are designed to achieve maximum efficiency of food production. This approach dominated until the end of the last century. There is no doubt that traditional farming has negative health implications due to the use of chemicals (Nieder et al.2018). The consequences are the increase in the number of diseases linked to obesity and gastrointestinal tract, such as gastritis, poisoning and cancer.

A fundamentally new approach to organic farming is based on biologization (Średnicka-Tober et al. 2016). Agricultural landscapes change when the number of monocultural fields decreases. Biologization encourages the introduction of new plant species into the ecosystem and thus it is conducive to biodiversity. In contrast to traditional farming, organic agriculture does not offer immediate strong results (Pinela et al. 2018). However, it sustains soil fertility and protect the agroecosystem. In recent decades, there has been a constant decrease in arable land due to soil dehumification, desertification, global climate changes and mineralization (Sparvoli et al. 2016). Redefining agriculture with the concept of biologization is an effective solution against soil degradation (De Schutter 2017).

The cultivation scheme examined in this study allows for a gradual transition from traditional to exclusively organic farming. Of conventional practices, only mechanical tillage was decided to be included. Even so, this solution is suitable for a smooth transition. Existing works confirm that organic farming improve a range of soil properties, such as fertility, structure and resistance (de Tombeur et al. 2018a, 2018b; 
The Impact of Growing Legume Plants under Conditions of Biologization and Soil Cultivation on Chernozem Fertility...

Gustavsson et al. 2011; The Rockefeller Foundation 2013). To transition from monoculture to permaculture requires gradually improving soil fertility and soil structure. Otherwise, farmers can expect the onset of mineralization and desertification, especially in areas with dry climates.

\section{CONCLUSION}

Binary mixtures of legumes with cereals or sunflowers with the use of biologization techniques help normalize soil moisture, micronutrient content, moisture resistance of soil aggregates and the amount of detritus. The present study revealed a steady tendency towards an increase of dead biomass (1.5 times), soil aggregates (one-third) and water resistance of those aggregates (9 per cent). In these conditions, crops had 3 to 8 per cent increase in yields.

\section{REFERENCES}

Akhtar, F., Lodhi, S.A., Khan, S.S., Sarwar, F. (2016). Incorporating permaculture and strategic management for sustainable ecological resource management. Journal of Environmental Management. 179: 31-37.

De Schutter, O. (2017). Report of the Special Rapporteur on the Right to Food. United Nations General Assembly. http:// www2.ohchr.org/english/issues/food/docs/A-HRC-1649.pdf.

de Tombeur, F., Sohy, V., Chenu, C., Colinet, G., Cornelis, J.T. (2018b). Effects of permaculture practices on soil physico-chemical properties and organic matter distribution in aggregates: A case study of the Bec-Hellouin farm (France). Frontiers in Environmental Science. 6: 116.

de Tombeur, F., Sohy, V., Chenu, C., Cornélis, J.T. (2018a). Permaculture practices favor organic matter storage in labile form in the macroaggregate pool. EGU General Assembly Conference Abstracts. 20: 4333.

Didur I., Pantsyreva H., Telekalo N. (2020). Agroecological rationale of technological methods of growing legumes. The Scientific Heritage. 52: 3-7.

Gustavsson, J., Cederberg, C., Sonesson, U., van Otterdijk, R., Meybeck, A. (2011). Global Food Losses and Food Waste - Extent, Causes and Prevention. FAO, Rome.

Hathaway, M.D. (2016). Agroecology and permaculture: Addressing key ecological problems by rethinking and redesigning agricultural systems. Journal of Environmental Studies and Sciences. 6(2): 239-250.

Hirschfeld, S., Van Acker, R. (2019). Permaculture farmers consistently cultivate perennials, crop diversity, landscape heterogeneity and nature conservation. Renewable Agriculture and Food Systems. 35(3): 342-351.

Kaushik, G., Singhal, P., Chaturvedi, S. (2018). Food Processing for Increasing Consumption: The Case of Legumes. In: Food Processing for Increased Quality and Consumption. Academic Press, Paris, pp. 1-28.

Nieder, R., Benbi, D.K., Reichl, F.X. (2018). Macro-and Secondary Elements and Their Role in Human Health. In: Soil Components and Human Health. Springer, Dordrecht, pp. 257-315.
Patil, S.B., Rajendran, K., Kumar, J., Sen Gupta D., Singh, S., Hamwieh, A., Mansur, C.M., Kumar, S. (2020). Adaptation of food legumes to problem soils using integrated approaches. Euphytica. 216:190.

Pinela, J., Petropoulos, S.A., Ferreira, I.C F.R. (2018). Innovative Legume Foods. Legumes. 235-260.

Ponisio, L.C., M'Gonigle, L.K., Mace, K.C., Palomino, J., de Valpine, P., Kremen, C. (2014). Diversification Practices Reduce Organic to Conventional Yield Gap. Proceedings of the Royal Society B: Biological Sciences. 282(1799): 1396.

Roberts, E. (2017). Agroforestry for the Northeastern United States: Research, Practice and Possibilities. In: Integrating Landscapes: Agroforestry for Biodiversity Conservation and Food Sovereignty. Springer, Cham, pp. 79-126.

Salleh, A.M., Rosli, F.M., Esa, N., Ibrahim, M.H. (2018). Permaculture Design: Linking Local Knowledge in Land Use Planning for House Compound. In: SHS Web of Conferences. EDP Sciences, Les Ulis, Vol. 45, pp. 03003.

Semedo, M.H. (2017). Agriculture should be integrated in climate change policies. Food and Agriculture Organization of the United Nations. http://www.fao.org/members-gateway /news/detail/en/c/357972/.

Sharma, A. (2017). Antinutritional factors as influenced by processing parameters during the production of some traditional legume based fermented foods of India. Thesis submitted to the University of North Bengal for the Award of Doctor of Philosophy in Botany.

Smith, L.G., Lampkin, N.H. (2019). Greener Farming: Managing Carbon and Nitrogen Cycles to Reduce Greenhouse Gas Emissions from Agriculture. In: Managing Global Warming. Academic Press, Paris, pp. 553-577.

Sparvoli, F., Laureati, M., Pilu, R., Pagliarini, E., Toschi, I., Giuberti, G., Fortunati, P., Daminati, M.G., Cominelli, E., Bollini, R. (2016). Exploitation of common bean flours with low antinutrient content for making nutritionally enhanced biscuits. Frontiers in Plant Science. 7: 928.

Średnicka-Tober, D., Barański, M., Seal, C., Sanderson, R., Benbrook, C., Steinshamn, H., Gromadzka-Ostrowska, J., et al. (2016). Composition differences between organic and conventional meat: A systematic literature review and meta-analysis. British Journal of Nutrition. 115(6): 994-1011.

Sun, Y.P., Yang, J.S., Yao, R.J., Chen, X.B., Wang, X.P. (2020). Biochar and fulvic acid amendments mitigate negative effects of coastal saline soil and improve crop yields in a three year field trial. Scientific Reports. 10(1): 1-12.

Symanczik, S., Gisler, M., Thonar, C., Schlaeppi, K., Van der Heijden, M., Kahmen, A., Boller, T., Mäder, P. (2017). Application of mycorrhiza and soil from a permaculture system improved phosphorus acquisition in Naranjilla. Frontiers in Plant Science. 8: 1263.

Tadele, M. (2020). Impacts of soil acidity on growth performance of faba bean (Vicia faba L.) and management options. Academic Research Journal of Agricultural Science and Research. 8(4): 423-431.

The Rockefeller Foundation (2013). Waste and spoilage in the food chain. Decision Intelligence Document. The Rockefeller Foundation. https://assets.rockefellerfoundation.org/app/ uploads/20130528220516/W asteand-Spoilage-in-theFood-Chain.pdf. 
The Impact of Growing Legume Plants under Conditions of Biologization and Soil Cultivation on Chernozem Fertility...

Tuyen, D.D., Chen, H., Vu, H.T.T., Hamwieh, A., Yamada, T., Sato, T., Yan, Y., Cong, H., Shono, M., Suenaga, K, Xu, D. (2016). $\mathrm{Ncl}$ synchronously regulates $\mathrm{Na}+\mathrm{K}+$ and $\mathrm{Cl}$ - in soybean and greatly increases the grain yield in saline field conditions. Scientific Reports. 6(1): 1-10.

Udomkun, P., Tirawattanawanich, C., Ilukor, J., Sridonpai, P., Njukwe, E., Nimbona, P., Vanlauwe, B. (2019). Promoting the use of locally produced crops in making cereallegume-based composite flours: An assessment of nutrient, antinutrient, mineral molar ratios and aflatoxin content. Food Chemistry. 286: 651-658.

Verde, B.S., Danga, B.O. and Mugwe, J.N. (2013). Effects of manure, lime and mineral $P$ fertilizer on soybean yields and soil fertility in a humic nitisol in the Central Highlands of Kenya. International Journal of Agricultural Science Research. 2(9): 283-291.

Vitari, C., David, C. (2017). Sustainable management models: Inovating through Permaculture. Journal of Management Development. 36(1): 14-36.
Wang, L., Butterly, C.R., Wang, Y., Herath, H.M.S.K., Xi, Y.G., Xiao, X.J. (2014). Effect of crop residue biochar on soil acidity amelioration in strongly acidic tea garden soils. Soil Use and Management. 30(1): 119-128.

Wobeng, N.B.M., Banfield, C.C., Megueni, C., Mapongmetsem, P.M., Dippold, M.A. (2020). Impact of legumes on soil microbial activity and $\mathrm{C}$ cycle functions in two contrasting Cameroonian agro-ecological zones. Pedobiologia. 81: 150662.

Xiong, X., Araya, A., Zhang, H., Araya, K., Teramoto, C., Ohmiya, K., Liu, F., Jia, H., Zhanf, C., Zhu, B., Wang, N., Neng, Q., Yang, Q., Li, W., Zhang, Z. (2012). Improvement of salt-affected soils by deep tillage-Part 1: Large-scale field tests in a saline soil (Solonchak) region. Engineering in Agriculture, Environment and Food. 5(1): 20-28.

Yadav, G.S., Das, A., Lal, R., Babu, S., Datta, M., Meena, R.S., Patil, S.B., Singh, R. (2019). Impact of no-till and mulching on soil carbon sequestration under rice (Oryza sativa L.)rapeseed [Brassica campestris (L.) var. rapeseed] cropping system in hilly agro-ecosystem of the Eastern Himalayas, India. Agriculture, Ecosystems and Environment. 275: 81-92. 